\title{
$\begin{array}{ll}\text { Ie portiQue } & \text { Le Portique } \\ \text { Revue de philosophie et de sciences humaines }\end{array}$ \\ e-Portique | 2005
}

\section{«Paralipomena »}

\section{OpenEdition}

Journals

Édition électronique

URL : https://journals.openedition.org/leportique/653

DOI : $10.4000 /$ leportique.653

ISSN : $1777-5280$

\section{Éditeur}

Association "Les Amis du Portique"

Référence électronique

《 «Paralipomena » », Le Portique [En ligne], e-Portique, mis en ligne le 15 juin 2005, consulté le 17 septembre 2022. URL : http://journals.openedition.org/leportique/653 ; DOI : https://doi.org/10.4000/ leportique.653

Ce document a été généré automatiquement le 17 septembre 2022

Tous droits réservés 


\section{«Paralipomena »}

1 Cette première livraison de e-Portique propose des articles parvenus à la rédaction, qui ne sont pas liés à un thème de la revue, ou qui viennent en complément d'un dossier. Ecrits de philosophie antique ou contemporaine, politique ou mathématique, "récits » ou «notions", ils forment des varia, du nom de cette rubrique ouverte traditionnellement à des contributions complémentaires, des textes inédits, des réflexions originales; ce sont non seulement des «suites et des ornements", mais aussi des « compléments précédemment inclassables, mais non moins indispensables » : des parerga et lipomena, pour citer le titre de l'ouvrage de Schopenhauer. 